\title{
BARRIER FOR IMPLEMENTATION OF IMPROVED COOK STOVE PROGRAM IN NEPAL
}

\author{
Er. Nawraj Bhattarai \\ Lecturer, Mechanical Engineering Department, Pulchowk Campus, Institute of Engineering, Tribhuvan University \\ Er. Sunil Risal \\ Lecturer, Mechanical Engineering Department, Pulchowk Campus, Institute of Engineering, Tribhuvan University
}

\begin{abstract}
More than 85\% of total population lives in rural part of Nepal. Traditionally, they are mostly using biomass based cooking stove for cooking purpose. To substitute those traditionally using cooking stoves, many Improved Cooking Stoves (ICS) programs are implemented and now more than three hundred thousand improved cooking stoves are already installed in rural households across the country. To accelerate the installation of such stoves more commonly in coming days, the past experiences and observed barriers for implementation of the programs are necessary to trace out. Thus, the present paper highlights the major barriers related to policy, technology, finance and social aspects of already disseminated ICSs based on literature review and questionnaires interview with relevant stakeholders. The statistical analysis of the study is carried out using SPSS statistical tool and presented.
\end{abstract}

Key words: Improved cooking stove (ICS), Stakeholders, and SPSS analyzing tool

\section{INTRODUCTION}

About 88 percent of total energy consumption is the basic component of traditional biomass resources. Out of the biomass resources about $78 \%$ is met by the fuel wood only. From the total consumption of 15 GJ per capita, in Nepal, actually 11.7 GJ per capita is supplied from the fuel wood. The majority of the fuel wood resources are combusted in the traditional wood stoves as the end use appliances which generate measurable smoke and flue gases with major health and environmental impact. The alternative option available to mitigate the wood fuel burning is the improved cook stove, which is implemented in only small percentage of households, about three hundred thousand. The rest, more than 30 lakh households are mostly still using traditional cook stoves to cook their daily food.
A history of ICS development program in Nepal dates back to $1950 \mathrm{~s}$ with the introduction of some Indian models. Since then, a number of Improved Cooking Stove Programs (ICSPs) have been promoted in rural communities of Nepal. A variety of stove designs with different dissemination strategies are promoted both by the government and the non government organizations.

During 1980s, interest and efforts were revived when the National Planning Commission included ICS in an attempt to address the pressing fuel wood problem. The government's concern for fuel wood conservation was also reflected with the inclusion of ICS dissemination efforts as an important component of FAO assisted Community Forestry Development Project (CFDP) in 1981.

In early 1990s, Research Center for Applied Science and Technology (RECAST) 
modified stoves design that can be built completely from cheap readily available local materials which have been promoted with various organizations to complement these efforts. Alternative Energy Promotion Centre/Ministry of Environment Science and Technology (AEPC/MoEST) executed National ICS Program with the support of Energy Sector Assistance Program (ESAP).In 1999, the National ICS Program is implemented in the middle hills of Nepal through the experienced non government organizations (NGOs) and government organizations (GOs).

\section{METHODOLOGY}

In this study both desk study and questionnaire interview with stakeholders were conducted. In desk study, the study of relevant documents related to ICS Program mainly policy including subsidy policy, rural energy policy, three year interim plan of Alternative Energy Technologies, Impact study on ICS, biomass components of AEPC/ESAP had been carried out. A comparative study on adopted government policies/plans on ICS and implementing agencies had been carried out. The deviation of government plan/policy and actual achievement of imported cook stove already disseminated in Nepal had been figured out. Based on review of ICS related activities, questionnaires for interview with the involved stakeholders had been prepared. A detail questionnaires based on desk study related to policy related, technological, financial and social aspects of improved cook stoves had been prepared.. Based on designed questionnaires, interview with relevant ministries, institutions and experts related to RETs had been done. These include mainly Alternative Energy Promotion Center(AEPC), Rural Energy Development Program(REDP),Biogas Support Program/Nepal( BSP/N), Center for Rural Technology/Nepal( CRT/N), Center for Energy Studies (CES), Department of Women Development, Department of Forest, International Center for Integrated Mountain Development (ICIMOD), National Academy of Science and Technology (NAST),Research Center for Applied Science and Technology(RECAST), Practical Action Nepal, Department of Mechanical Engineering, Institute of Engineering( IOE), and Kathmandu Engineering College(KEC) etc. Collected data from the survey had been complied/processed and analyzed by using SPSS statistical tools.

Table 1, Name of organizations involved in interview and frequency table

\begin{tabular}{|c|c|c|c|c|c|}
\hline & & Frequency & Percent & Valid Percent & $\begin{array}{l}\text { Cumulative } \\
\text { Percent }\end{array}$ \\
\hline \multirow[t]{9}{*}{ Valid } & AEPC & 1 & 4.5 & 4.5 & 4.5 \\
\hline & Bio Nepal & 1 & 4.5 & 4.5 & 9.1 \\
\hline & BSP, Nepal & 1 & 4.5 & 4.5 & 13.6 \\
\hline & DFRS & 3 & 13.6 & 13.6 & 27.3 \\
\hline & ICIMOD & 1 & 4.5 & 4.5 & 31.8 \\
\hline & CES(Ioe) & 1 & 4.5 & 4.5 & 36.4 \\
\hline & IOE & 4 & 18.2 & 18.2 & 54.5 \\
\hline & $\begin{array}{l}\text { Kathmandu } \\
\text { Enginnering } \\
\text { College }\end{array}$ & 1 & 4.5 & 4.5 & 59.1 \\
\hline & NAST & 1 & 4.5 & 4.5 & 63.6 \\
\hline
\end{tabular}




\begin{tabular}{|l|l|l|l|l|l|}
\hline & Pratical Action & 2 & 9.1 & 9.1 & 72.7 \\
\cline { 2 - 6 } & $\begin{array}{l}\text { Renewable Energy } \\
\text { Project }\end{array}$ & 2 & 9.1 & 9.1 & 81.8 \\
\cline { 2 - 6 } $\begin{array}{l}\text { Researching Centre } \\
\text { of } \\
\text { Energy(RECAST) }\end{array}$ & 1 & 4.5 & 4.5 & 86.4 \\
\hline $\begin{array}{l}\text { V.D.C. Energy } \\
\text { Development } \\
\text { Project }\end{array}$ & 1 & 4.5 & 4.5 & 90.9 \\
\cline { 2 - 6 } $\begin{array}{l}\text { V.D.C. Technical } \\
\text { Centre }\end{array}$ & 1 & 4.5 & 4.5 & 95.5 \\
\hline & WDD & 1 & 4.5 & 4.5 & 100.0 \\
\hline & 22 & 100.0 & 100.0 & \\
\hline
\end{tabular}

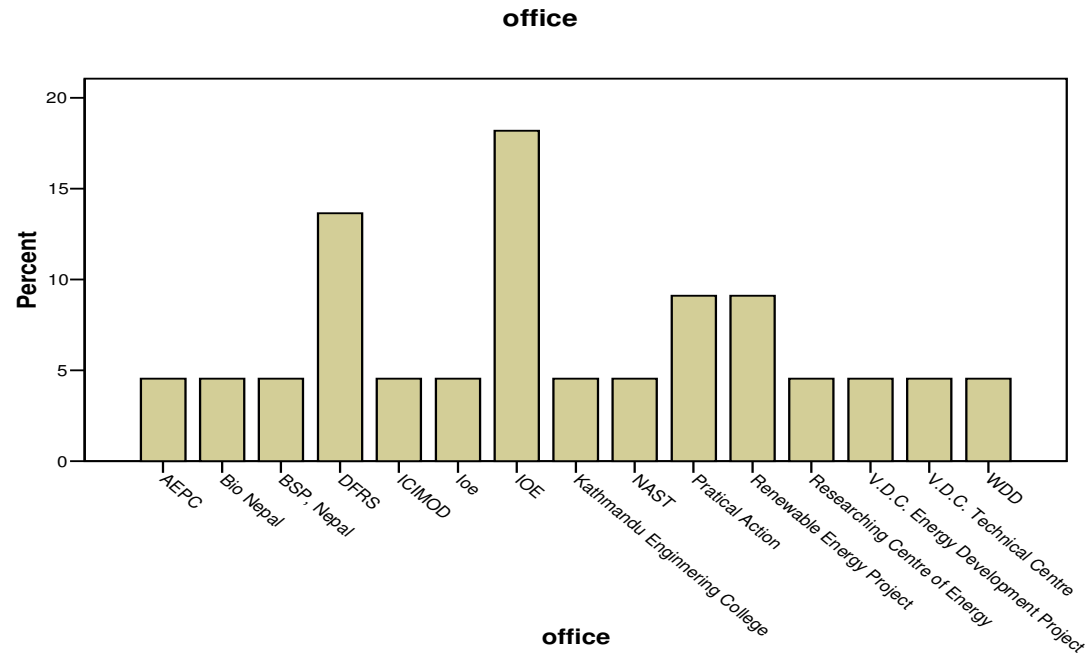

Figure 1, Percent wise contribution of responding organizations

\section{DESK STUDY OBSERVATION AND ANALYSIS}

Although periodic five year plan started in 1956 but the address of ICS was done in Eighth Plan (1992-1997) by fixing the target of installation of 2,50,000 ICS in rural households of Nepal. In Eighth Year Plan, the target could not obtain but the achievement of the plan was the establishment of Alternative Energy Promotion Centre (AEPC). In Ninth Five Year Plan (1997-2002) also the target of 2, 50,000 ICS was fixed but the achievement was only about $20 \%$ of the target. In Tenth Year Plan (2002-2007) about $85.14 \%$ of the target 2, 50,000 ICS was achieved in the first four years and the role of AEPC/ESAP and UNDP/REDP is leading for the achievement of the target.

There was not direct subsidy provision on the renewable subsidy policy 2000 for ICS. The current subsidy policy 2006 also do not provide direct subsidy for hilly and mid hilly region but helps to promote local level organizations. The rural energy policy 2006 has tried to address ICS for implementation 
of economic activities for poverty reduction. Similarly, three year interim plan has set the target of installation of 3, 00,000 ICS in mid hill and high hilly region of the country and hoped to reduce deforestation and negative impact of environment by introducing ICS in rural areas.

From the analysis, it has found that the development and implementation of ICS sector is more dominant by the foreign development partners and it is the challenges for Nepalese Government to assure the sect oral development of ICS program by institutionalizing and self propagating in market for the sustainable development in the future.

\section{INTERVIEW RESULT AND ANALYSIS}

Twenty two questionnaires forms results have been analyzed using SPSS analyzing tool. The questionnaires are filled with AEPC, Department of Forest, Biogas Support Program, ICIMOD, Bio-Nepal, CES, IOE, Kathmandu Engineering College, NAST, Practical Action, REP, RECAST, REDP, and WDD etc.

\subsection{Policy related}

About 59\% of respondents respond that the previous adopted policies related to improved cook stove program was satisfactory, however, about $41 \%$ of them blame for not providing direct subsidy as less priority to the sector. About $45.5 \%$ of the people figured out as the weakness in implementation of program for failure for meeting the five year target on ICS and $40.9 \%$ people said that subsidy policy related to ICS is traditional. Similarly, about $59 \%$ of the respondents are agreeing with the recently promulgated Rural Energy Policy is as a relevant policy whereas $50 \%$ responds that the Interim Three Year Plan is as an unclear planning document for ICS. About
$63.3 \%$ respondents agree with the relevancy of overall policies as favorable for the development of the ICS program and $63.6 \%$ respondents believes that National Improved Cooking Stove Program target is as normally achievable.

\subsection{Technology related}

About 55\% of respondent responds that the already constructed ICS technology was as traditional. The technical training for ICS was satisfactory on the view of $68 \%$ respondents. About $50 \%$ people figured out that the technical aspect of ICS is the main barrier of implementation of ICS on rural part of Nepal.

\subsection{Financial related}

About 59\% of respondent respond that it was marginal financial burden to construct the ICS in rural houses. About $45 \%$ response was against the service cost charges to installer for making the ICS to rural people. Similarly, about $50 \%$ respondents said that the direct subsidy for installation should not be given to the end users but $36.4 \%$ is for the direct subsidy.

\subsection{Social aspect related}

About $50 \%$ respondents respond that the social barrier for the implementation of ICS was normal. About $45.5 \%$ people responds that the barrier for the traditional social aspect for empowerment of women was normal and about $50 \%$ of responds pointed out that the direct women involvement in the ICS program was good.

\section{CONCLUSION}

In the past, the adopted policies related to ICS were satisfactory; but the weakness was in implementation of the program. The current policies also are in satisfactory level. The adopted technology on ICS was traditional and possessed technical barrier for 
the effective implementation of program. It has found that it was injustice to the rural people to pay cash money for the installation of the ICS and the social barrier for the implementation of the program was moderate. The development and implementation of ICS sector is more dominant by the foreign development partners. Thus in coming days financial allocation to the sector may be the major barrier for Nepalese Government in the absence of donor agencies.

\section{ACKNOWLEDGEMENT}

We would like to express our sincere gratitude to the AEPC for financial support. Similarly we are also very thankful to SSR Engineering Consultancy, Research \& Training Center Pvt. Ltd. family for their endless efforts during the study.

\section{REFERENCES}

[1] Annual Report 2007, Centre for Rural Technology, Nepal (CRT/N).

[2] A study on Analysis of Rural Energy Programs with Respect to their linkages with poverty reduction, April 2005, AEPC/ESAP.

[3] Development of Liquid Bio-fuel out of the Traditional Biomass Resources to Generate Renewable fuel for Rural Development in Nepal, R.B. Singh and N.Bhattarai, RETURD-06, Kathmandu, Nepal.

[4] Economic Survey of Nepal, Ministry of Finance.

[5] National Planning Commission, Seventh Five -Year Plan 1985-1990 (BS 2042-47), HMG/Nepal,

[6] National Planning Commission, Eight Five -Year Plan 1992-1997 (BS 204954), HMG/Nepal,

[7] National Planning Commission, Ninth Five -Year Plan 1997-2002 (BS 20542059), HMG/Nepal

[8] Renewable Energy in Nepal - Progress at a Glance from 1998 to 2003. By
J.N.Shrestha, T.R. Bajracharya, S.R. Shakya and Bijay Giri, RETURD-03, Kathmandu, Nepal.

[10] Renewable (rural) energy subsidy delivery mechanism, 2006; Government of Nepal, Ministry of Environment Science and Technology, Alternative Energy Promotion Centre.

[11] Renewable energy policy in Nepal: An analysis; By J.N Shrestha and S.Pradhan, Center for Energy Studies, NEA Conference, 2005.

[12] Study on Barriers for Implementation of Cooking Stove Program in Nepal, Alternative Energy Promotion Center (AEPC), 2008.

[13] Subsidy for Renewable (Rural) Energy, 2006, June 2007, Altenative Energy Promotion Centre.

[14] Year wise Achievements (1997-2006), June 2007, Alternative Energy Promotion Centre, Rural Energy Development Program.

http://www.aepc.org.np 
